\title{
Model management of innovative development of industrial enterprises
}

\author{
Roman Golov ${ }^{1, *}$, Tamara Narezhnaya ${ }^{2}$, Nikolay Voytolovskiy ${ }^{3}$, Vladimir Mylnik ${ }^{1}$ and \\ Elena Zubeeva ${ }^{1}$ \\ ${ }^{1}$ Moscow Aviation Institute, Volokolamskoe highway, 4, 125993, Moscow, Russia \\ ${ }^{2}$ Moscow State University of Civil Engineering, Yaroslavskoe sh., 26, 129337, Moscow, Russia \\ ${ }^{3}$ Sankt-Petersburg State Economic University, Sadovaya street, 21, 191023, St. Petersburg, Russia
}

\begin{abstract}
The purpose of the study is to develop the theoretical and methodological provisions, as well as the practical recommendations for the management of the innovative development of the industrial enterprises of a vertically integrated structure, which is considered as one of the mechanisms to improve its competitiveness. The article analyzes the technology of the innovative development of the economic systems, examines the current trends and identified the problems of the management of their innovative development, studies the technology of the management parameters of the life cycle of the products in the industrial enterprises and forms the criteria for the effectiveness of the innovative development management. The result of the study is the development of a structural and parametric model of the innovative enterprise management and the creation of a mechanism to improve the efficiency of its activities.
\end{abstract}

\section{Introduction}

In the conditions of the vertical integration of the industrial production systems, not only the possibility of acquiring ready-made innovations increase due to the growth of the financial power of the company, but also the development of the innovation on their own through the use of a whole factor range. As a key factor in the development of the innovative activities of the industrial enterprises should be considered the possibility of the operational resources redistribution between economic entities in the interests of the balanced development of their innovation and investment activities.

\section{Materials and methods}

In the subsystem of the innovative development on the basis of the developed innovative strategy of the company implemented the processes associated with the definition of specific objectives of the management of innovative development, the development plans and development programs of the innovative development and the definition of management technologies of the innovative development. The innovative changes (product,

\footnotetext{
*Corresponding author: roman_golov@rambler.ru
} 
raw material, technological, organizational and market orientation) resulting from the implementation of the innovative processes are subject to control. The analysis and assessment of the efficiency of the company innovative development are related to the adjustment as a direct strategy of the innovative activities and the overall development strategy of the company [1].

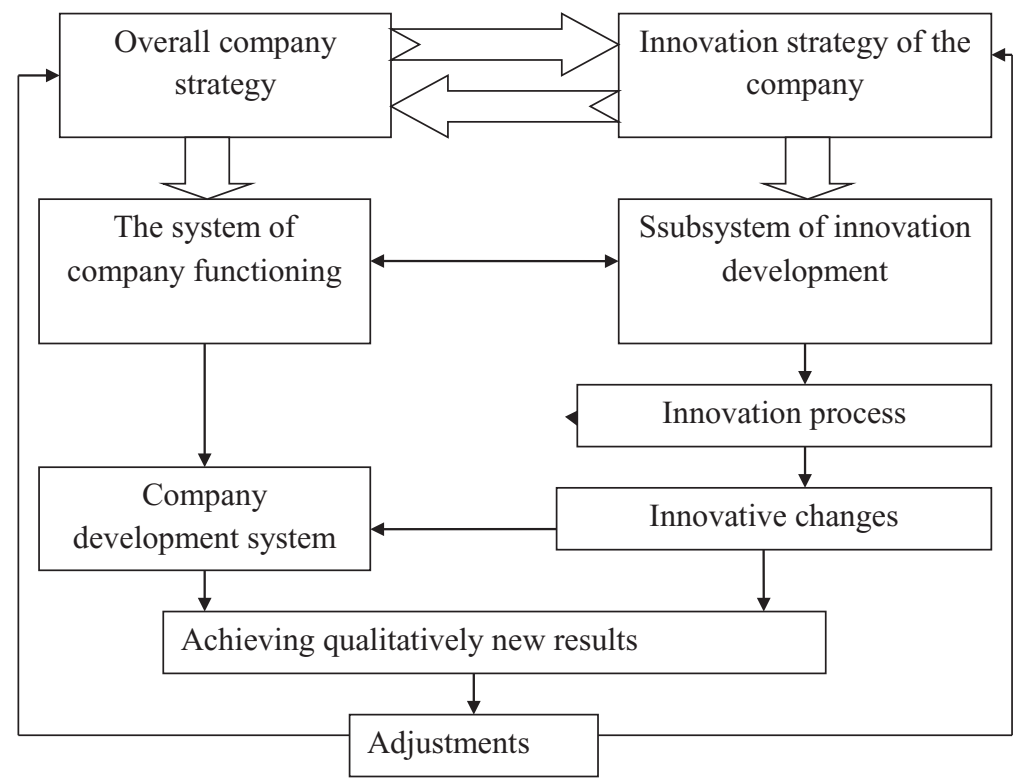

Fig. 1. Scheme of innovative development of economic system as an object of management at microeconomic level.

Since the basic basis of the innovative development of any economic system is technology, the composition of the relevant technologies has been determined (figure 1).

A comprehensive study of the systematized technologies of the innovative development of the economic systems allowed analyzing the modern trends of the innovative development management of the economic systems.

The generalization of the results of the known researches showed that the main trends of the innovative development management of the economic systems are the following [2].

First, there is a tendency of the management schemes complication of the innovative development of the economic systems, due to the acceleration of the scientific and technological progress, on the one hand, and the increasing saturation of the market, on the other hand. As a result, the share of the innovative products against the background of the traditional products of the economic systems has increased significantly. These circumstances are associated with the increasing requirements for the quality of the innovative development management of the economic systems [3]. 


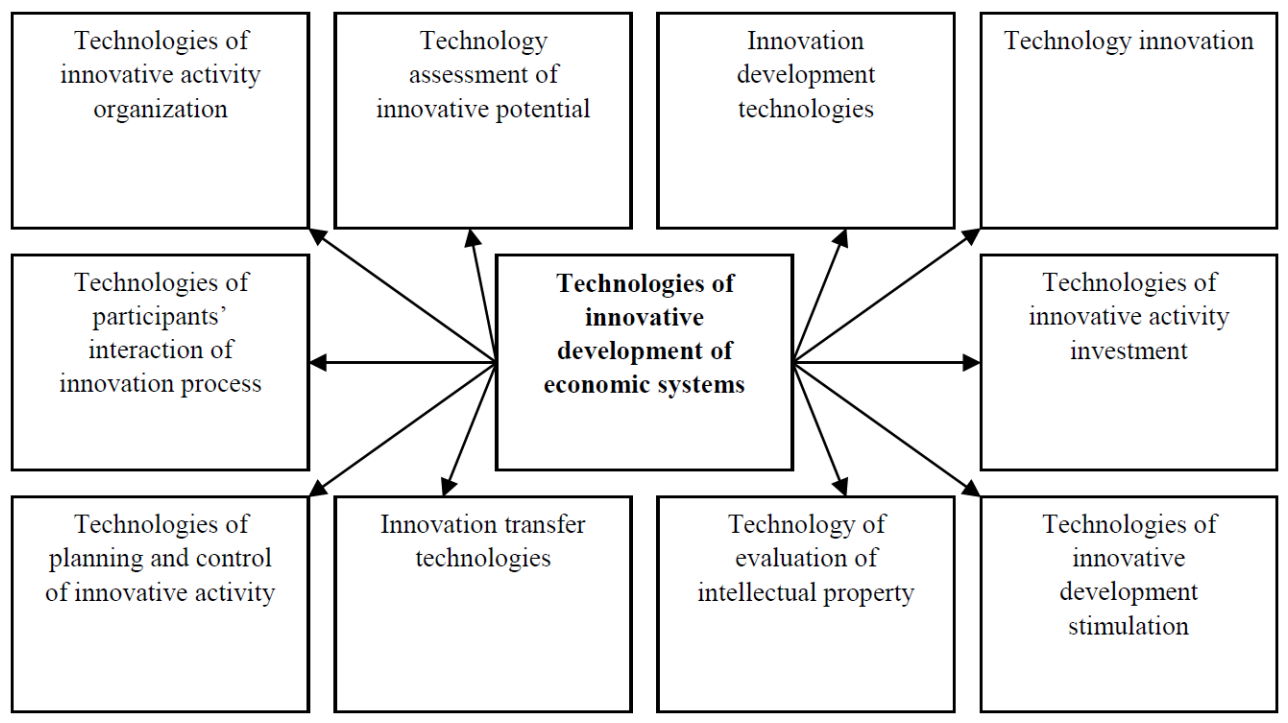

Fig. 2. Technologies of innovative development stages of economic systems.

This is the main trend in the innovative development management of the economic systems, from which follow all other trends.

Secondly, there is a tendency of the efforts redistribution in the innovative development management of the economic systems, due to the growing role and importance of the human capital as the fundamental basis of the emerging knowledge economy. These circumstances impose increased requirements for the competence of the managers of the innovative development management system of the economic systems [4].

Third, since the performance of the production and commercial activities of any economic system in the area of the innovation is significantly influenced by the management of the functioning and organizational structure process within which the innovative processes are carried out, in the conditions of the growing market uncertainty, the flexibility in the resources use and compliance with market requirements is of fundamental importance.

Fourth, in the conditions of the market saturation growth, the problem of the innovative activity commercialization of the economic systems, which requires new management decisions, is increasing.

Fifthly, in the conditions of the increasing concentration and centralization of the capital, when the transnational corporations have become the core of the global postindustrial economy, providing more than a quarter of its gross product, there is a tendency of the processes complexity of the innovative and investment development management of the enterprises included in the vertically integrated structures [5].

In the process of studying the innovative development management problems of the industrial enterprise of the vertically integrated structure, it was found that the key ones are the following:

- holding companies interaction problem in the frameworks of a single economic mechanism;

- innovative component integration problem of the industrial enterprises development in the strategy of the long-term development;

- issue of the securities of the different levels by the parent company and subsidiaries, complicated by the underdevelopment of the domestic stock market; 
- problem of the attracting long-term investments in the implementation of organizational innovations;

- problem of the innovative development uniformity of the technological chain links in the production system;

- problem of the company innovative development related to "corporate interests";

- investment resources redistribution problem within the company;

- problem of the significant part competitiveness of the domestic industrial products;

- restoration problem of the lost production technologies and cooperative technological ties;

- the problem of the aging and qualification degradation of the stuff, along with the continued growth of the overall level of the wear and tear of the equipment and the loss of the technology;

- optimization problem of the production and technological infrastructure of the enterprises;

- interaction problem of the industrial enterprises with financial institutions.

On the basis of the identified problems of the innovative development management of the industrial enterprises in the paper, an algorithm for their solution is proposed, the structure of which is shown in figure 2.

On the basis of the proposed algorithm (figure 3), the paper analyzes the directions of the balanced development of the innovation and investment cycles in the industrial vertically integrated structures [6].

\section{Results}

At the first stage, the analysis of the tools and technologies for managing the parameters of the innovation life cycle was carried out, the stages of which are shown in figure 4.

\begin{tabular}{|c|}
\hline $\begin{array}{l}1 \text { Analysis of tools and technologies for parameters management of innovation life cycle in industrial } \\
\text { enterprises of vertically integrated structure }\end{array}$ \\
\hline$\downarrow$ \\
\hline $\begin{array}{l}2 \text { Analysis of investment cycle management tools at industrial enterprises of vertically integrated } \\
\text { structure }\end{array}$ \\
\hline \\
\hline $\begin{array}{l}3 \text { Factor analysis of influence of vertically integrated structure on development of reproductive and } \\
\text { technological structures }\end{array}$ \\
\hline$\downarrow$ \\
\hline 4 Analysis of innovation life cycle and its relation to investment cycle \\
\hline \\
\hline $\begin{array}{l}5 \text { Formation of criteria management efficiency of innovative development of industrial enterprise of } \\
\text { vertically integrated structure in interests of balanced development of innovative and investment } \\
\text { cycles }\end{array}$ \\
\hline 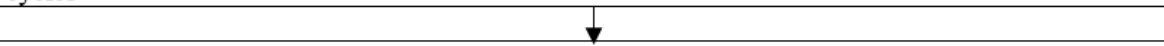 \\
\hline $\begin{array}{l}6 \text { Formation of structural and parametric model of innovative development management of industrial } \\
\text { enterprise of vertically integrated structure }\end{array}$ \\
\hline 1 \\
\hline $\begin{array}{l}7 \text { Development of mechanism for improving efficiency of innovative development management of } \\
\text { industrial enterprise vertically integrated structure }\end{array}$ \\
\hline 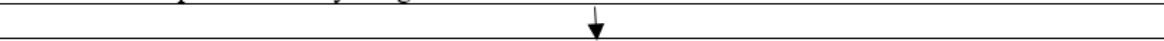 \\
\hline $\begin{array}{l}8 \text { Development of set of guidelines for construction and use of innovative development management } \\
\text { system of industrial enterprises of vertically integrated structure }\end{array}$ \\
\hline
\end{tabular}

Fig. 3. Algorithm of problems solving of innovative development management of industrial enterprises. 
When the considering the innovation as a result of the materialization of the idea obtained by the investing in the processes of the creating the new raw materials, new products, new technologies, new organizational structures, obtaining new market opportunities, it showed in the work that in the vertically integrated structures of the innovation, regardless of the depth of the innovation changes $[7,8]$ :

- initiated by the needs of the production,

- related to the structure of the economic system,

- perform, first of all, a reproductive function,

- are designed to carry the novelty for the industry in the country and in the world.

At the marketing stage, the prospects for production the development with vertical integration are revealed.

At the innovation initiation stage, a hypothesis of a new product creation is formed, which can potentially be discussed by several teams of the vertically integrated structure.

At the stage of new product development, the enterprises of the vertically integrated structure are carried out the organization of the innovative processes, associated with the search for investment resources, including within the structure.

At the production stage, the practical problems of the innovative renewal are identified, both of the links of the main production structure and the infrastructure of the vertically integrated system.

At the promotion (sales) stage of the enterprises products, there is a need to use the distribution channels of the vertically integrated structure, providing the most effective introduction of a new product to the market due to the possibilities of the advertising, branded distribution network, etc.

At the stage of the adjustment to bring the products in line with the actual needs of the consumers, the information capabilities of the vertically integrated structure are used to provide feedback to the consumers, production and technological capabilities of the enterprises of the structure, etc.

At the diffusion stage, the growth of the innovative products sales of the enterprise of the vertically integrated structure can be increased by connecting the production capacities of the other enterprises included in the structure.

At the stabilization stage of the market volume of the innovative products, the use of resources of the vertically integrated structure allows increasing the efficiency of the processes of the product price reduction without loss of its functional qualities and improvement of the operational characteristics.

At the stage of decline in the volume of the innovative products market, the possibilities of the vertically integrated structure allow moving the obsolete products to the other less developed markets, ensuring its production, including at controlled enterprises and prolonging the life cycle of products. 


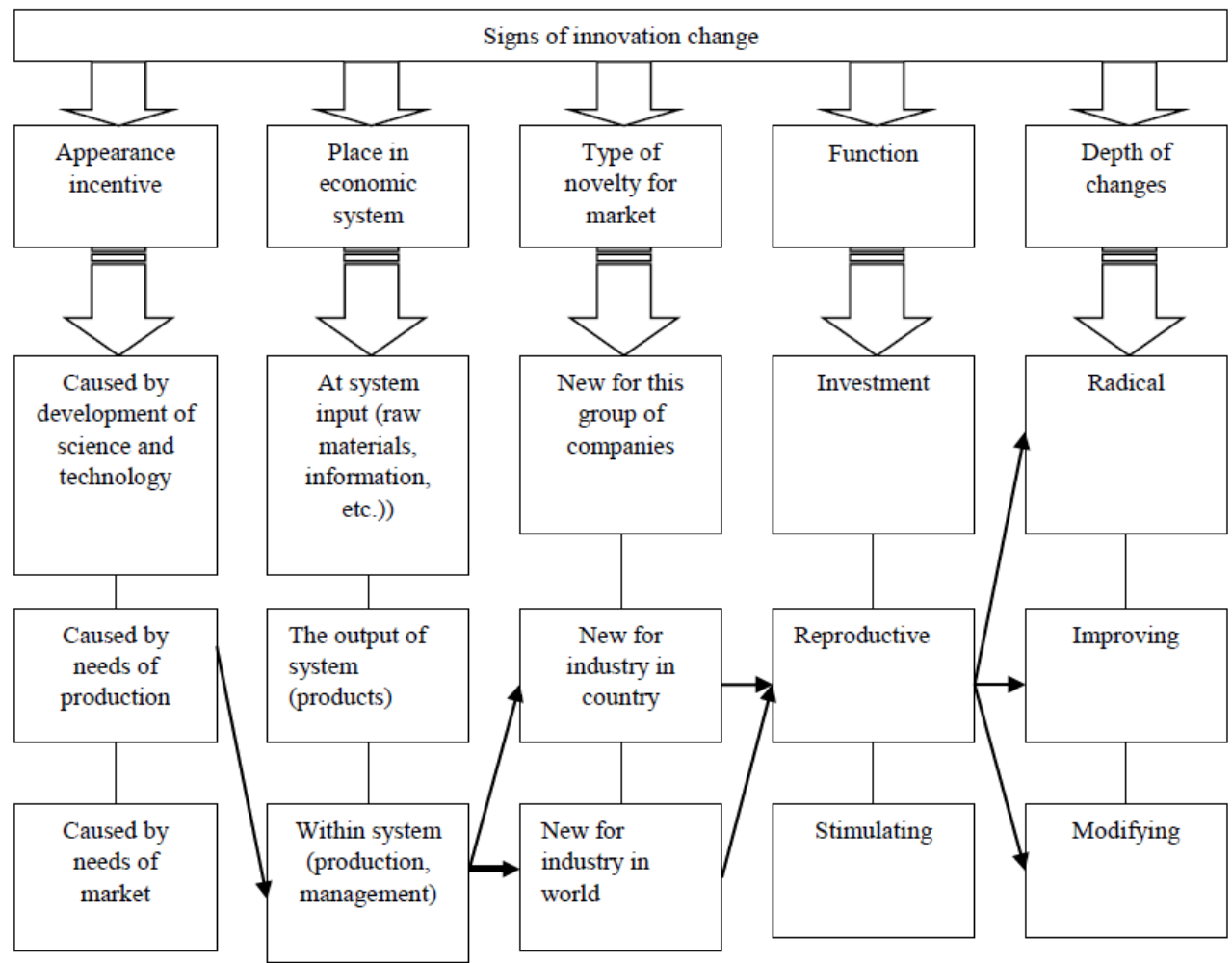

Fig. 4. Characteristics of innovation production structure.

The main tools and technologies for the parameters management of the innovation life cycle in the industrial enterprises of the vertically integrated structure are given in the table 1.

Table 1. Tools and techniques of parameters managment of innovation life cycle.

\begin{tabular}{|c|c|c|c|}
\hline No. & $\begin{array}{c}\text { Life cycle } \\
\text { stage }\end{array}$ & $\begin{array}{c}\text { Managed } \\
\text { Options }\end{array}$ & Technologies and tools \\
\hline 1 & Marketing & Production and sales opportunities & $\begin{array}{c}\text { Technologies for creating } \\
\text { products, determining prices, } \\
\text { distribution and promotion }\end{array}$ \\
\hline 2 & Initiation & Direction of implementation & Feasibility study \\
\hline 3 & Development & $\begin{array}{c}\text { Organization of innovation processes, finding } \\
\text { investment resources }\end{array}$ & $\begin{array}{c}\text { Technology for structuring } \\
\text { product functions }\end{array}$ \\
\hline 4 & Production & $\begin{array}{c}\text { Parameters of innovative renewal of links in the } \\
\text { main production structure and infrastructure }\end{array}$ & $\begin{array}{c}\text { Intensification of technological } \\
\text { processes, continuity and } \\
\text { streaming }\end{array}$ \\
\hline 5 & Promotion & Terms of promotion & $\begin{array}{c}\text { Advertising in mass-media, sites, } \\
\text { Internet projects }\end{array}$ \\
\hline 6 & Adjustment & Conformity of the products to the actual \\
requests of consumers & sales \\
\hline 7 & Diffusion & Speed and diffusion boundaries & $\begin{array}{c}\text { Exhibitions, fairs, surveys trial } \\
\text { Technologies for spreading } \\
\text { innovation over communication } \\
\text { channels in time and space }\end{array}$ \\
\hline 8 & Stabilization & $\begin{array}{c}\text { Reducing the cost of production, without loss of } \\
\text { its functional qualities, improving performance }\end{array}$ & $\begin{array}{c}\text { Functional and value analysis, } \\
\text { improving innovation }\end{array}$ \\
\hline
\end{tabular}


Along with commodity, grocery, technological, organizational and market innovation inherent in the individual businesses, the vertical integration enables the organizational innovation, synergies and associated companies with the following combination of factors [9]:

- expansion of the marketing research opportunities through a wide range of the specialized organizations;

- improvement of the inter-firm engineering infrastructure, ensuring its balance;

- development of the in-house information network, providing the improved accuracy, reliability and timeliness of the provided information;

- rationalization of the energy opportunities use through the internal reallocation of the load;

- improving the capacity of the intra-company logistics networks.

- increase of the production and technological capabilities by the combining industrial capabilities of the enterprises;

- increase of the financial stability of the enterprises for the financial resources redistribution;

\section{Conclusion}

When the building and using of the management system of the innovative development of the industrial enterprise it is advisable to carry out on the basis of monitoring data audit of the innovative projects, to establish weight coefficients for the evaluating the innovative activity effectiveness of the individual enterprises and to consider as a priority criterion the innovative activity effectiveness.

\section{References}

1. C. Furlong, S. De Silva, K. Gan, L. Guthrie, R. Considine, Journal of Environmental Management 191, 83-95 (2017)

2. K. Anagnostis, K. Alexios, Procedia Economics and Finance 9, 120-132 (2014)

3. L. Shan, A. Yu, Y.Wu, Habitat International 59, 90-100 (2017)

4. E.M. Kiseleva, M.L. Nekrasova, M.A. Mayorova, M.N. Rudenko, V.S Kankhva, International Review of Management and Marketing 6, 95 (2016)

5. S. Gupta, N. K. Malhotra, Journal of Business Research 69, 5671-5681 (2016)

6. T.W. Chung, The Asian Journal of Shipping and Logistics 32, 257-264 (2016)

7. N.G. Bagautdinova, A.V. Sarkind, I.R. Gafurove, Procedia Economics and Finance 14, 23-29 (2014)

8. A.A. Anfinogentova, M.N. Dudin, N.V. Lyasnikov, O.D. Protsenko, Economy of Region 14, 638-650 (2018), doi:10.17059/2018-2-24

9. B. Alexander, B. Vladislav, Journal of Physical Education and Sport 16, 910-913 (2016), doi:10.7752/jpes.2016.03143 